\title{
PENGARUH MODEL PROJECT BASED LEARNING (PjBL) DENGAN PENDEKATAN STEM TERHADAP PENGUASAAN KONSEP DAN KETERAMPILAN BERPIKIR KRITIS SISWA
}

\author{
Afni Nur Afifah ${ }^{1}$, Nur Ilmiyati ${ }^{2}$, Toto ${ }^{2}$ \\ 1,2,3 Program Studi Pendidikan Biologi, Universitas Galuh, JI. R. E. Martadinata No.150, Ciamis, Indonesia \\ Email: afninurafifah@gmail.com
}

\begin{abstract}
The purpose of this study is to determine the effect of the PJBL model using the STEM approach on students' mastery towards the concepts and critical thinking skills. The research is conducted in the first and second week of April 2019. This research uses the Pre Experimental method involving students of class X MA 2 Ciamis. The sampling is carried out by using purposive sampling technique. The instrument used is a concept mastery test in the form of multiple choice, and a critical thinking skills test in the form of a critical thinking skills test adapted from Piaw (2004). Data obtained from the two instruments are processed statistically. The results of the study indicates that the increased of concepts mastery showing moderate criteria (31\%); the increase of critical thinking skills comes up with high criteria (75\%).
\end{abstract}

Keywords: PjBL, STEM, Mastery of Concepts, Critical Thinking Skills.

\section{ABSTRAK}

Tujuan penelitian ini adalah untuk mengetahui pengaruh model PjBL menggunakan pendekatan STEM terhadap penguasaan konsep dan keterampilan berpikir kritis siswa. Penelitian dilakukan di minggu pertama dan kedua bulan April 2019. Penelitian ini menggunakan metode Pre Eksperimental. Populasi penelitian ini adalah Siswa kelas X MA Negeri 2 Ciamis. Pengambilan sampel menggunakan teknik purposive sampling. Instrumen yang digunakan adalah tes penguasaan konsep berupa pilihan ganda, tes keterampilan berpikir kritis berupa soal tes keterampilan berpikir kritis yang diadaptasi dari Piaw (2004). Data yang diperoleh dari kedua intrumen tersebut diolah secara statistik. Hasil penelitian $31 \%$ peningkatan penguasaan konsep yang menunjukkan kriteria sedang dan $75 \%$ peningkatan keterampilan berpikir kritis yang menunjukkan kriteria tinggi.

Kata Kunci: PjBL, STEM, Penguasaan Konsep, Keterampilan Berpikir Kritis

Cara sitasi: Afifah, A. N., Ilmiyati, N \& Toto. (2020). Pengaruh Model Project Based Learning (PjBL) dengan Pendekatan STEM Terhadap Penguasaan Konsep dan Keterampilan Berpikir Kritis Siswa. J-KIP (Jurnal Keguruan dan IImu Pendidikan) , 1 (2), 33-40. 


\section{PENDAHULUAN}

Pendidik harus kreatif dan inovatif dalam menerapkan strategi pembelajaran sehingga siswa mampu menggunakan kemampuan berpikir tingkat tinggi. Sesuai dengan tuntutan keterampilan abad 21, seperti keterampilan berpikir kritis, kreatif, memiliki kemampuan memecahkan masalah, dan membuat keputusan. Berdasarkan hasil wawancara pada guru mata pelajaran biologi kelas X di MA Negeri 2 Ciamis, bahwa proses pembelajaran masih dengan cara konvensional yang hanya duduk, dengar dan diam. Peserta didik juga kurang mampu mengembangkan teknik mereka dalam menyerap informasi yang didapatkan dari guru. Menurut Yustyan, Widodo \& Pantiwati, (2015) pada dasarnya peserta didik memiliki kemampuan dalam penguasaan konsep dan kemampuan berpikir yang baik, seperti halnya kemampuan berpikir kritis dalam belajar, tetapi terkadang keterampilan tersebut tidak dapat berkembang dengan baik.

Masyarakat dengan ciri globalisasi, kemajuan iptek, dan kemampuan menerima arus informasi yang padat dan cepat, tentunya memerlukan generasi yang mampu menghadapi segala tantangan serta siap menyesuaikan diri dengan situasi baru tersebut. Pendidikan berkewajiban mempersiapkan generasi yang memiliki kemampuan tersebut, antara lain manusia melek teknologi dan melek pikir, yang mampu " think globally but act locally", pembangunan generasi masa depan merupakan syarat dari upaya pembaruan pendidikan (Tirtahardja \& Sulo, 2005). Pemerintah Indonesia berupaya memperbaharui dan menerapkan kurikulum yang mempunyai prinsip fleksibilitas, bahwa pendidikan pada saat ini harus menyesuaikan dengan karakteristik peserta didik abad 21 .

Dalam kegiatan belajar sangat diperlukan interaksi positif yang terjadi antara guru dan peserta didik yang menyenangkan dan tidak membosankan. Dalam kegiatan belajar mengajar diperlukan sebuah pendekatan. Mulyono (2016) berpendapat bahwa pendekatan merupakan titik tolak dalam memandang sesuatu, suatu filsafat atau keyakinan yang tidak selalu mudah membuktikannya. Oleh karena itu, perlu adanya alternatif atau inovasi baru dari pendidik dalam proses pembelajaran. Salah satunya yaitu dengan mengembangkan pendekatan dan model pembelajaran.

STEM merupakan akronim dari Science, Technology, Engineering dand mathematics. Reeve (Yanuar, 2018) mengadopsi definisi pendidikan STEM sebagai pendekatan interdisiplin pada pembelajaran yang didalamnya peserta didik menggunakan STEM dalam konteks nyata yang mengkoneksikan antara sekolah, dunia kerja, dan dunia global, sehingga menggunakan literasi STEM yang memampukan peserta didik bersaing dalam era ekonomi baru yang berbasis pengetahuan. STEM (Science, Technology, Engineering and Mathematics) adalah pendekatan yang melibatkan siswa dalam kegiatan metakognitif. STEM memiliki sebuah Implementasi di kelas yang menyediakan peluang bagi siswa untuk memahami pentingnya integrasi yang berbeda disiplin dan aplikasinya (Anwari et.al. dalam Murnawianto, Sarwanto \& Rahardjo, 2017). Penerapan STEM memiliki peluang besar untuk melatih keterampilan berpikir siswa melalui karakteristiknya (Murnawianto, Sarwanto \& Rahardjo, 2017). Selain pendekatan, model pembelajaran juga sangat penting untuk diperhatikan dalam mengatur jalannya proses pembelajaran. Menurut Kemendikbud (2017) Project Based Learning (PjBL) adalah suatu model pembelajaran yang menggunakan suatu proyek dalam proses pembelajaran, dan berpusat pada siswa (Student centered). Model PJBL memberikan kebebasan kepada peserta didik untuk merencanakan aktivitas belajar mereka, melaksanakan proyek secara kolaboratif, dan pada akhirnya menghasilkan produk kerja yang dapat dipresentasikan kepada orang lain (Kemendikbud, 2017). Project Based Learning (PjBL) adalah pembelajaran inovatif yang mendorong peserta didik untuk melakukan penyelidikan bekerja secara kolaboratif dalam meneliti dan membuat proyek yang menerapkan pengetahuan mereka dari menemukan hal-hal baru, mahir dalam penggunaan teknologi dan mampu menyelesaikan permasalahan (Suranti, Gunawan \& Sahidu, 2016).

Pembelajaran yang diterapkan oleh guru tentu diharapkan mampu meningkatkan hasil belajar dan perilaku siswa. Haladyna (1997) menjelaskan bahwa perilaku siswa terdiri dari dua dimensi, yaitu types of content behavior (pengetahuan fakta, konsep, teori, prinsip, dan prosedur), dan type of mental behavior (kemampuan memahami, memecahkan masalah, berpikir kritis dan kreatif) yang merupakan 
perilaku mental tingkat tinggi (the higher forms of mental behavior) (Rusyana, 2014). Pernyataan ini bermakna bahwa proses pembelajaran siswa harus mencapai pada perubahan perilaku baik itu perilaku yang berkaitan dengan materi pelajaran, seperti pemahaman konsep, maupun perilaku yang berkaitan dengan mental anak, seperti keterampilan berpikir kritis, sehingga mampu terbangun prilaku mental tingkat tinggi untuk menghadapi tantangan-tantangan pada abad 21.

Konsep merupakan dasar bagi proses mental yang lebih tinggi untuk merumuskan prinsip dan generalisasi. Penguasaan konsep merupakan hasil utama dari pendidikan, mencakup pengetahuan tentang kategori, klasifikasi, dan hubungan antara dua atau lebih kategori (lebih kompleks). Penguasaan konsep menjelaskan gambaran suatu peristiwa yang menjadikan seseorang mampu untuk berkomunikasi, mengklasifikasikan ide, gagasan dari suatu gambaran atau peristiwa yang terjadi. Sama halnya dengan siswa yang mampu memberikan tanggapan terhadap pertanyaan atau rangsangan yang didapatnya selama proses pembelajaran (Dahar dalam Suranti, Gunawan \& Sahidu, 2016; Anderson dan Krathwol dalam Suranti, Gunawan \& Sahidu, 2016 ; Bundu dalam Arisanti, Sopandi \& Widodo, A, 2016).

Berpikir Kritis adalah pemikiran yang masuk akal dan reflektif yang berfokus pada memutuskan apa yang diyakini atau dilakukan (Ennis,1985). Keterampilan berpikir kritis merupakan pemikiran yang bersifat selalu ingin tahu terhadap informasi yang ada untuk mencapai suatu pemahaman yang mendalam (Yustyan, Widodo \& Pantiwati, 2015). Keterampilan berpikir kritis dapat mendukung tercapainya tujuan pembelajaran biologi yang tercantum dalam standar isi yang diantaranya adalah memupuk sikap ilmiah yaitu tidak mudah percaya tanpa ada dukungan hasil observasi empiris, memahami konsep-konsep biologi dan penerapannya untuk menyelesaikan masalah dalam kehidupan sehari-hari. Keterampilan berpikir kritis menurut Facione (Yustyan, Widodo \& Pantiwati, 2015) meliputi interpretation, analysis, inferensi, evaluation, explanation, and selfregulation.

STEM alam PjBL dapat meningkatkan minat belajar siswa, pembelajaran yang bermakna, dan membantu siswa dalam memecahkan suatu masalah serta menunjang karir dimasa yang akan datang. STEM dalam PjBL juga memberikan tantangan dan motivasi bagi siswa, karena hal tersebut mampu melatih siswa berpikir kritis, analisis dan meningkatkan keterampilan berpikir tingkat tinggi (Tseng, et al.; dan Capraro, et al., dalam Afriana, Permanasari \& Fitriani, 2016) Dengan demikian perpaduan antara model pembelajaran Project Based Learning (PjBL) dengan menggunakan pendekatan STEM dapat mengoptimalkan kegiatan pembelajaran yang mendukung pencapaian keberhasilan belajar pada penguasaan konsep dan kemampuan berpikir kritis siswa.

Penelitian ini bertujuan untuk mengetahui pengaruh model Project Based Learning (PjBL) dengan pendekatan STEM terhadap penguasan konsep, dan untuk mengetahui pengaruh model Project Based Learning (PjBL) dengan pendekatan STEM terhadap keterampilan berpikir kritis.

\section{METODE PENELITIAN}

Penelitian ini menggunakan metode Pre Eksperimental, dimana penelitian ini hanya menggunakan kelas eksperimen saja. Desain penelitian yang digunakan adalah One-Group PretestPostest Design. Pada desain ini terdapat pretest, sebelum perlakuan. Dengan demikian hasil perlakuan dapat diketahui lebih akurat, karena dapat membandingkan dengan keadaan sebelum di beri perlakuan (Sugiyono, 2017).

\section{Tabel 1. Rancangan Eksperimen}

\begin{tabular}{ccc}
\hline Pretest & Perlakuan & Postest \\
\hline $\mathrm{O}_{1}$ & $\mathrm{X}$ & $\mathrm{O}_{2}$ \\
\hline
\end{tabular}

Keterangan: $0_{1}$ : Pretest

$X$ : Perlakuan

$\mathrm{O}_{2}$ : Postest 
Populasi dalam penelitian ini adalah siswa kelas X MA Negeri 2 Ciamis pada semester genap tahun ajaran 2018/2019. Sampel yang diambil dalam penelitian ini adalah satu kelas dari 4 kelas $X$ MIPA di MA Negeri 2 Ciamis tahun ajaran 2018/2019 yaitu kelas X MIPA 1 sebagai kelas eksperimen dengan jumlah siswa 36 orang. Pengambilan sampel pada penelitian ini menggunakan teknik purposive sampling, dimana pengambilan sampel ditentukan sesuai dengan kebutuhan penelitian.

Instrumen yang digunakan dalam penelitian ini disesuaikan dengan kriteria jenis penelitian kuantitatif yang ditentukan. Tes penguasaan konsep dan keterampilan berpikir kritis berupa postest dan pretest. Instrumen yang digunakan berupa soal pilihan ganda yang berbeda untuk setiap variabelnya.

Data hasil pretest dan postest dilakukan analisis data dengan melakukan uji normalitas, dengan rumus :

$$
X^{2}=\sum \frac{(O i-E i)^{2}}{E i}
$$

(Nurgana, 1993)

Keterangan :

Oi : Frekuensi Observasi

El : frekuensi Ekspetasi

Setelah uji Normalitas dilakukan dilanjutkan dengan pengujian hipotesis, untuk data penguasaan konsep $\chi^{2}$ daftar $>\chi^{2}$ hit maka data ini berdistribusi normal yang kemudian dilanjutkan uji hipotesis dengan uji $Z$.

$$
Z=\frac{\frac{x}{n}-p}{\sqrt{\frac{p(1-p)}{n}}}
$$

(Nurgana, 1993)

Keterangan :

$\mathrm{x}=$ banyak data yang termasuk

kategori hipotesa

$\mathrm{n}=$ banyak data

$p=$ proporsi pada hipotesa

Dari hasil perhitungan uji hipotesis data penguasaan konsep dengan menggunakan uji z diperoleh nilai Zhitung $\leq \mathrm{Z}$ tabel maka hipotesis ditolak.

Kemudian Untuk data keterampilan berpikir kritis $\chi^{2}$ daftar $<\chi^{2}$ hit maka data ini berdistribusi tidak normal yang kemudian dilanjutkan uji hipotesis dengan uji wilcoxon (Nurgana, 1993).

$$
W=\frac{n(n+1)}{4}-x \sqrt{\frac{n(n+1)(2 n+1)}{24}}
$$

Dari hasil perhitungan uji hipotesis data ketermpilan berpikir kritis dengan menggunakan uji wilcoxon diperoleh nilai $W_{\text {hitung }}<W_{\text {daftar, }}$ maka hipotesis diterima atau terjadi pengaruh. 


\section{HASIL DAN PEMBAHASAN}

Hasil penelitian ini diperoleh dengan pemberian tes awal dan tes akhir yang berbentuk soal pilihan ganda sebanyak 15 soal untuk mengukur penguasaan konsep dan 15 soal keterampilan berpikir kritis. Soal tersebut telah diuji validitas, reliabilitas dan taraf kesukaranya.

Berdasarkan hasil penelitian yang telah dilakukan diperoleh data sebagai berikut:

Tabel 2. Hasil Rata-rata pretest, postest dan N.Gain

\begin{tabular}{lllllll}
\hline Variabel & $\begin{array}{l}\text { Rata-rata } \\
\text { pretest }\end{array}$ & $\begin{array}{l}\text { Rata-rata } \\
\text { postest }\end{array}$ & $\begin{array}{l}\text { Rata-rata } \\
\text { Gain }\end{array}$ & $\begin{array}{l}\text { Rata-rata } \\
\text { Indeks gain }\end{array}$ & $\begin{array}{l}\text { Rata-rata } \\
\text { N.Gain (\%) }\end{array}$ & Kriteria \\
\hline $\begin{array}{l}\text { Penguasaan } \\
\text { Konsep }\end{array}$ & 52 & 67 & 15 & 0,31 & 31 & Sedang \\
$\begin{array}{l}\text { Keterampilan } \\
\text { Berpikir kritis }\end{array}$ & 41 & 85 & 45 & 0,75 & 75 & Tinggi \\
\hline
\end{tabular}

Pada Tabel 2, diperoleh nilai data penguasaan konsep dengan rata-rata N.Gain sebesar 31\% yang menunjukkan peningkatan dengan kriteria sedang, sedangkan pada keterampilan berpikir kritis diperoleh rata-rata N.Gain sebesar $75 \%$ yang menunjukan peningkatan yang memiliki kriteria tinggi. Pengujian data dilakukan menggunakan uji normalitas. Data yang dihitung dalam uji normalitas yaitu menggunakan data N.gain dengan menggunakan taraf signifikansi $1 \%(\alpha=0,01)$ untuk penguasaan konsep dan keterampilan berpikir kritis.

Berdasarkan hasil perhitungan uji Normalitas yang dilakukan menggunakan program microsoft excel 2007 menunjukkan bahwa nilai dari data penguasaan konsep yaitu $x^{2}$ hit $=9,39 \leq x^{2}$ daftar $=11,30$. Hal ini menunjukkan bahwa data tersebut berdistribusi normal. Setelah itu uji hipotesis dilakukan dan memperoleh nilai $Z$ hit $0,625 \leq Z$ tabel 1,65 , hal ini menunjukkan bahwa model Project Based Learning (PjBL) dengan Pendekatan STEM (Science, Technology, Engineering dand mathematics) tidak berpengaruh terhadap penguasaan konsep siswa

Penemuan di lapangan menunjukan bahwa pembelajaran yang menggunakan strategi student center learning belum terbiasa mereka lakukan, kebiasaan strategi belajar yang menggunakan metode konvensional memberikan pengaruh kepada siswa saat belajar. Pada proses pembelajarannya, siswa hanya mendengarkan apa yang guru sampaikan tanpa adanya pemanfaatan sumber belajar yang lainnya. Sebagian besar siswa tidak menggunakan teknologi untuk mencari informasi tentang konsep-konsep pada materi yang dipelajari. Sedangkan pembelajaran dengan menggunakan model Project Based Learning (PjBL) memerlukan waktu yang cukup banyak dalam memecahkan masalah untuk menemukan konsep sebenarnya sehingga kecil kemungkinan siswa mendapatkan informasi lebih mengenai materi tersebut.

Dari penemuan penelitian tersebut, sejalan dengan beberapa faktor ketidak berpengaruhan. Dalam pembelajaran yang menggunakan model Project Based Learning ( $\mathrm{PjBL}$ ) memiliki kekurangan, diantaranya memerlukan waktu banyak dalam pembelajarannya. Selain itu pembelajaran berbasis proyek ini berfokus pada aktivitas siswa. Dalam penelitian ini model Project Based Learning (PjBL) dipadukan dengan pendekatan STEM (Science, Technology, Engineering and mathematics). STEM tidak memberikan pengaruh pada penguasaan konsep siswa karena kemungkinan diakibatkan oleh adanya hambatan-hambatan implementasi pendekatan STEM, sesuai dengan pendapat Ejiwale (2013) yang menyatakan bahwa meskipun hasil National Assessment of Educational Progress (NAEP) terbaru menunjukkan peningkatan dalam pengetahuan matematika dan sains siswa AS, sebagian besar siswa masih gagal mencapai tingkat kemahiran yang memadai.

Hambatan - hambatan yang ada dalam implementasi Pendekatan STEM diantaranya adanya Poor preparation and inspiration of students. Siswa lebih terbiasa belajar dengan metode-metode konvensional, sehingga siswa belum memiliki kesiapan, motivasi dan inpirasi untuk belajar dalam penerapan pendekatan STEM. Selanjutnya Lack of connection with individual learners in a wide variety of ways. Kurangnya hubungan siswa terhadap hal yang dapat meningkatkan pembelajaran di 
bidang STEM. kemudian Lack of support from the school system. Kurangnya dukungan dari sistem sekolah. Terakhir Poor method of assessment. Metode penilaian hasil pembelajaran tidak hanya didasarkan pada ranah kognitif, tapi harus mencakup ranah afektif dan psikomotorik.

Data keterampilan berpikir kritis memperoleh nilai $x^{2}$ hit $=30,54 \geq x^{2}$ daftar $=11,30$. Hal ini menunjukkan bahwa data tersebut berdistribusi tidak normal. Dan diperoleh nilai uji hipotesis $W_{\text {hit }}=91$ $\leq W_{\text {tabel }}=313$, dengan taraf signifikansi $\alpha=0,05$ menunjukkan bahwa hipotesis diterima atau terdapat pengaruh pada model Project Based Learning (PjBL) dengan Pendekatan STEM (Science, Technology, Engineering dand mathematics) terhadap keterampilan berpikir kritis. Hasil dari data penelitian ini juga diperkuat oleh penelitian sebelumnya yaitu Sularmi, Dwiyono \& I (2018) bahwa model Project based Learning (PjBL) dapat meningkatkan keterampilan berpikir kritis siswa, hal ini terjadi karena siswa memiliki peran aktif dan mengalami peningkatan motivasi dalam pembelajaran.

Penggunaan pendekatan STEM dapat meningkatkan kemampuan berpikir siswa secara logis. Hal ini sesuai dengan pendapat Anwari et al. (Murnawianto, Sarwanto \& Rahardjo, 2017), yang menyatakan bahwa STEM melibatkan siswa dalam kegiatan metakognitif. Kegiatan metakognitif ini meliputi proses memilih, mencari, bertanya, membagi, menyusun hipotesis, dan proses pembuatan keputusan (Sularmi, Dwiyono \& I, 2018). Dalam implementasinya STEM menyediakan peluang bagi siswa untuk memahami pentingnya integrasi yang berbeda disiplin dan aplikasinya dalam belajar. Dengan demikian siswa dapat meningkatkan pemikiran logis mereka melalui impelementasi tersebut. Sejalan dengan itu, STEM juga dapat meningkatkan kemampuan siswa dalam memecahkan masalah yang diajukan dan menyelesaikannya dengan pemikiran kritis. Sesuai dengan pendapat lain dari Murnawianto, Sarwanto \& Rahardjo (2017) yang menyatakan bahwa Pendidikan STEM memiliki karakteristik komprehensif (problem solving and critical analysis) dalam memberi kesempatan bagi siswa untuk melatih kemampuan berpikir mereka. Penerapan pendidikan STEM memiliki peluang besar untuk melatih keterampilan berpikir siswa melalui karakteristik dalam pendekatannya.

Pendekatan STEM memiliki tujuan yang sesuai dengan karakteristik pendidikan abad 21, salah satunya keterampilan berpikir kritis yaitu pemikiran yang bersifat selalu ingin tahu terhadap informasi yang ada untuk mencapai suatu pemahaman yang mendalam. Dengan demikian pembelajaran dengan menggunakan pendekatan STEM dapat meningkatkan keterampilan berpikir kritis siswa. Yanuar (2018) juga berpendapat bahwa keterampilan abad 21 yang dapat dikembangkan melalui pembelajaran dengan pendekatan STEM adalah keterampilan berpikir kritis, berpikir kreatif, berkomunikasi dan berkolaborasi.

Dengan menggunakan model Project Based Learning (PjBL) yang dipadukan dengan pendekatan STEM (Science, Technology, Engineering and mathematics) dapat meningkatkan keterampilan berpikir kritis siswa. Hal ini disebabkan karena aktivitas yang dilaksanakan dalam pembelajaran lebih berorientasi pada keterlibatan aktif siswa, yang mana mampu menstimulus siswa untuk berpikir kritis. Dengan demikian penggunaan model Project Based Learning ( $\mathrm{PjBL}$ ) dengan pendekatan STEM (Science, Technology, Engineering and mathematics) dapat meningkatkan keterampilan berpikir kritis pada siswa. Sejalan dengan pendapat Capraro et al., (Afriana, Permanasari \& Fitriani, 2016) yang mengungkapkan bahwa STEM dalam PjBL memberikan tantangan dan memotivasi siswa karena melatih siswa berpikir kritis, analisis dan meningkatkan keterampilan berpikir tingkat tinggi.

\section{KESIMPULAN}

Berdasarkan hasil analisis dan pembahasan yang telah dilakukan, maka dapat diambil kesimpulan: 1) Model Project Based Learning (PjBL) dengan pendekatan STEM (Science, Technology, Engineering and mathematics) tidak terdapat pengaruh terhadap peningkatan penguasan konsep siswa. Hal ini disebabkan oleh siswa yang belum terbiasa dengan strategi belajar menggunakan STEM dan lebih terbiasa dengan pembelajaran konvensional, selain itu kurangnya dukungan baik internal maupun eksternal; 2) Model Project Based Learning (PjBL) dengan 
pendekatan STEM (Science, Technology, Engineering and mathematics) berpengaruh terhadap peningkatan keterampilan berpikir kritis siswa. Meskipun project based learning (PjBL) dengan STEM tidak berpengaruh pada penguasaan konsep tetapi project based learning ( $\mathrm{PjBL}$ ) dengan STEM bisa merangsang keterampilan berpikir kritis siswa melalui kegiatan-kegiatan yang ada didalamnya.

\section{REKOMENDASI}

Peneliti lain disarankan untuk dapat melakukan penelitian serupa mengenai Model Project Based Learning ( $\mathrm{PjBL}$ ) dengan pendekatan STEM (Science, Technology, Engineering and mathematics) terhadap penguasaan konsep dan keterampilan berpikir kritis. Dengan menerapkan upaya lain secara teoritis yang dapat dikolaborasikan dengan strategi ini, agar tidak hanya berpengaruh terhadap keterampilan berpikir kritis, tetapi dapat berpengaruh juga terhadap penguasaan konsep.

\section{UCAPAN TERIMAKASIH}

Ucapan terima kasih disampaikan untuk guru mata pelajaran biologi kelas X MIPA MA Negeri 2 Ciamis yang telah mengizinkan penelitian ini dilaksanakan.

\section{DAFTAR PUSTAKA}

Afriana, J., Permanasari, A., \& Fitriani, A. (2016). Penerapan Project Based Learning Terintegrasi STEM untuk Meningkatkan Literasi Sains Siswa Ditinjau dari Gender. Jurnal Inovasi Pendidikan IPA.

Arisanti, W. O., Sopandi, W., \& Widodo, A. (2016). Analisis Penguasaan Konsep dan Keterampilan Berpikir Kreatif Siswa SD Melalui Project based Learning. Edu Humaniora : Jurnal Pendidikan Dasar.

Ejiwale, J.A. (2013). Barriers to successful implementation of STEM education. Journal of Education and Learning, 7(2), 63-74.

Ennis, R. H. (1985). "At Outline of Goals for A Critical Thingking Curriculum" in Deveolping Mind : A Resource Book For Teaching Thinking. Revised Edition, Vol 1. California: ASCD.

Haladyna, T. M. (1997). Writing test items to evaluate higher order thinking. Boston, MA: Allyn and Bacon.

Kemendikbud. (2017). Buku Guru IImu Pengetahuan Alam. Jakarta: PT.Tiga Serangkai Pustaka Mandiri.

Mulyono, N. (2016). Kurikulum dan Pembelajaran. Bandung: Rizqi Press.

Murnawianto, S., Sarwanto, \& Rahardjo, S. B. (2017). Stem-Based Science Learning In Junior High School: Potency For Training Students' Thinking Skill. Pancaran Pendidikan .

Nurgana, E. (1993). Statistika Penelitian. Bandung: Cv. Permadi.

Rusyana, A. (2014). Keterampilan Berpikir. Jakarta: Penerbit Ombak.

Sugiyono. (2017). Metode Penelitian Kuantitatif, Kualitatif, dan R\&D. Bandung : Alfabeta, CV. 
Sularmi, Dwiyono, H. U., \& I, N. R. (2018). pengaruh project based learning terhadap kemampuan berpikir kritis. jurnal Pendidikan .

Suranti, N. M., Gunawan, \& Sahidu, H. (2016). Pengaruh Model Project Based Learning Berbantuan Media Virtual Terhadap Penguasaan. Jurnal Pendidikan Fisika Dan Teknologi .

Tirtahardja, U \& Sulo, S. (2005). Pengantar Pendidikan. Jakarta: Rineka Cipta.

Yanuar, Y. (2018). Unit Pembelajaran STEM . Bandung: South East Asia Ministry of Education Organization (SEAMEO) Regional Centre for Quality.

Yustyan, S., Widodo, N., \& Pantiwati, Y. (2015). Peningkatan Kemampuan Berpikir Kritis Dengan Pembelajaran Berbasis Scientific Approach Siswa Kelas X SMA Panjura Malang. Jurnal Pendidikan Biologi Indonesia . 